Bileviciute, E., Draksas, R., Nevera, A., \& Vainiute, M. (2019). Competitiveness in Higher Education:

The Case of University Management. Journal of Competitiveness, 11(4), 5-21. https://doi.org/10.7441/

joc. 2019.04 .01

\title{
COMPETITIVENESS IN HIGHER EDUCATION: THE CASE OF UNIVERSITY MANAGEMENT
}

\section{- Egle Bileviciute, Romualdas Draksas, Andrius Nevera, Milda Vainiute}

\begin{abstract}
As a response to current global trends in the field of higher education and studies, the attitude has become prevalent in the European Commission and among member states of the European Union (EU) that major reforms are required to help European higher education successfully compete under the conditions of globalization and a knowledge-based economy. Studies focused on student personal success and citizenship education are inseparable from technological advancement and international mobility opportunities, the integration of top international teachers, collaborative studies with students from various countries, as well as other factors that can help prepare open, tolerant, creative and well-prepared graduates. The quality of research and education remains a priority in European higher education. University management must be based on community spirit, the autonomy of academic units, as well as on a results-oriented approach leading toward greater efficiency and financial stability. The aim of the present article is to examine the effects of management innovations in higher education using the case of Mykolas Romeris University, as this learning institution was one of the first in Lithuania to apply the modern study management methods. The research goal is to determine whether or not there is a difference between general higher education trends in Lithuania and the trends observed at MRU. Descriptive statistical methods were applied in the data analysis, with the relations of the data, the indexes as well as speed of change calculated. Strength among links is assessed using the Pearson correlation coefficient. The article analyses the use of modern innovation management methods that have helped the university survive in the difficult conditions of greater competition and reduced state funding.
\end{abstract}

Keywords: higher education management, competition, funding, university, Lithuania JEL Classification: I123, I125

Received: July, 2019

1st Revision: September, 2019

Accepted: September, 2019

\section{INTRODUCTION}

The role of higher education becomes even more unique in the society with the increasing demand for highly qualified and socially responsible people in the labor market. It is predicted that before 2025 half of all jobs will need to be filled by highly qualified workers. Thanks to digital technologies, new economy job classifications and the duties involved have created a need 
for workers who are more flexible and who have more complex skill sets. Resourcefulness and adaptability have become particularly important, as people are expected to be able to process complex information, think independently and creatively, make clever uses of resources (including digital resources), and successfully communicate (Vázquez-Burgete et al., 2012; Ungerman et al., 2018). Europe can only reach these training and employment goals with universities and higher education systems that can successfully operate in the fields of education, scientific research and innovations, all which must be accomplished while maintaining a close relationship with the public. Reforming higher education is both the duty of individual member states as well as a primary task at the EU level to develop world-class education and schooling (European Commission, 2017). Higher education institutions and their connections to scientific research and innovation help create new jobs and ensure economic growth and prosperity, thus these institutions are vital partners in implementing the European Union strategy focused on promoting and maintaining economic growth.

University management reforms have been either directly or indirectly affected by global social, economic, cultural and demographic changes in the European countries and throughout the world. Universities must be open to innovation, react to the changes and challenges in their environment, and become involved in the competitive struggle in the fields of both education and scientific research. Likewise, university management reforms are either directly or indirectly affected by global social, economic, cultural and demographic changes throughout the world and in European countries. Universities need to be more proficient in managing changes to deal with the internal and external factors which influence their long-term financial sustainability (Rogers, 2019). Management methods, leadership, profitability criteria, investment, as well as marketing strategies adopted from business have become common in higher education (Bilevičiūtè et al., 2012; Gižienè et al., 2008; Prisăcariu, 2015; Baltaru \& Soysal, 2018).

Lithuanian higher education is facing challenges as a result of global trends in university development. At present, Lithuanian institutions do not seem to be satisfying their stakeholders, be they students, the international academic community, the general public, or international and domestic business interests. A worsening demographic situation, the limited financial capabilities of the state, low international competitiveness, low pay for lecturers and scientists, as well as fragmentation among study programs and scientific research groups all have led to inefficient experimental development and stunted innovative activities. These problems as well as other challenges require immediate attention. Lithuania must develop ways to distribute its current funds more effectively and encourage greater quality in the research and education system, in order to meet the needs of the domestic population, e.g. by increasing international competitiveness (Pruskus et al., 2015). As one national quality assessment report states: "Higher education institutions should promote their recognition services to current and prospective students, as they may not be aware that recognition is even a possibility" (Integrating academic recognition and quality assurance: practical recommendations, 2019).

\section{THEORETICAL BACKGROUND}

\subsection{Status and trends of higher education}

The positive effect of the European Union (EU) and its international dimension are recognized by the member states, social partners and the higher education sector. Still, European higher 
education systems continue to have a number of problems, including a mismatch between the required and available skills throughout Europe, the constant and increasing social divide, as well as the lack of innovation and effective collaboration among various parts of higher education systems (Craig, 2017; Grizane et al., 2017). Education has been determined as one of the most important factors in the development of the contemporary knowledge-based economy (Gižiene et al., 2008).

As the demographic crisis deepens, competition among universities is becoming stronger. Only universities that offer modern and flexible programs can remain successful in the market for higher education and studies. (Becket \& Brooks, 2008). Nevertheless, the change of the number of students at European universities depends not only on demography, but also on socio-economic issues. There is intense competition in the education services market, and higher education institutions strive to gain a competitive edge, so it is important for them to understand and meet the expectations of their stakeholders. For the strategic management of higher learning, the quality of education from a student perspective becomes a key element of interest (Pârvu \& Sandu, 2019). Secondary school students as well as graduates with bachelor's degrees from the Baltic States are increasingly interested in studying at Western European universities, which are perceived to provide a higher level of education and better future career opportunities.

By analyzing the dynamics of student numbers (Figure 1), we can notice that the state of the post-Soviet Union model demonstrates an ongoing decrease in student enrollment. Even in such high-developed states such as the Czech Republic and Slovenia the same trend has held since 2010. Notably, in Lithuania, Poland and Estonia, the number of students is steadily decreasing, while in Germany and the United Kingdom it is constantly growing, with research results showing "an important and systematic variation in the way governments of different countries adjusted public funding for tertiary education during the economic crisis. In general, funding for tertiary education was more negatively affected in countries with a deeper economic crisis." (Skrbinjek \& Lesjak, 2018). Further, "Europe and the inter-mobility between the west and the east are quite weak. Such one direction flow limits the further development of education in Eastern Europe and forms an unbalanced situation in the European continent" (Liu, 2018).
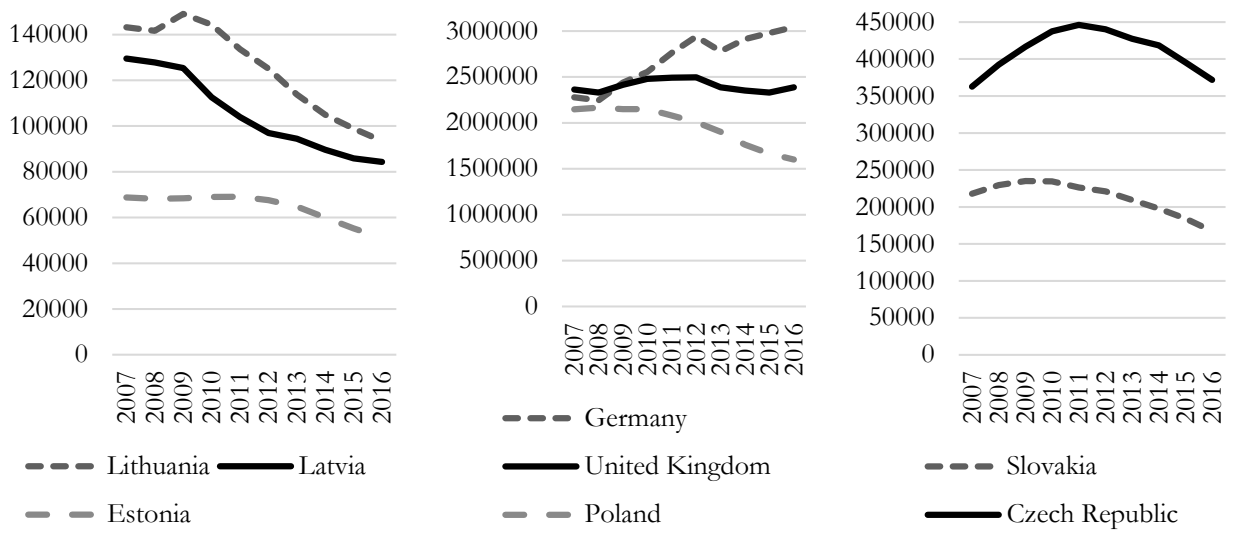

Fig. 1 - Dynamics of students' number. Source: Eurostat (2019) 
One of Lithuania's main strategic goals is to make Lithuanian education a sustainable basis for improving the well-being of the state, however, now, the education system suffers from fragmented reforms. The Lithuanian higher education and the number of educated people remains one of the advantages of the country's innovation system. Many Lithuanian citizens seek higher education abroad. However, the number of students arriving to study in Lithuania from the 27 EU or EEA countries was only 0.2 percent, while the average in the 27 European member states is 3.6 percent. An analysis of the status of Lithuanian higher education points to a series of negative factors. The overall number of high-school graduates and university admissions is quickly decreasing (Eurostat, 2019).

\subsection{Higher education reform}

Social and economic innovations and high-level scientific research are the main factors when striving to improve the social and economic situation and quality of life throughout Europe. There is no universal model of a single quality standard that can be used to assess the quality criteria of institutes of higher education (Noaman et al.). Knowledge, science and innovations should be the main prospects of growth and competitiveness (Valioniene, 2016). When living under the conditions of a lack of public resources, it is necessary to review the effectiveness of public expenditure (Ginevicius et al., 2018). How well the science and higher education policy matches the quickly-changing demands and how successfully the goals are implemented largely depends on the flexibility and adaptability of strategic planning. The competition within higher education and newly arising challenges have caused universities to reorganize their management. Management methods, leadership, profitability criteria, investment, marketing strategies adopted from business have become usual in higher education (Blagojevic Popovic et al., 2018).

"As higher education comes under increasing pressure from policy-makers, nationally and internationally, to contribute more directly to economic development, tensions between more traditional missions of universities and their more recent entrepreneurial makeovers create major dilemmas for academic staff regarding their roles and responsibilities" (Sugruea \& Solbrekkeb, 2017). The higher education market currently forming in the field of European higher education, its increasing competition (the most advanced universities and networks, in order to compete with each other, restructure their management and create conditions for the fastest possible transfer of knowledge, technology, scientific inventions and innovations into the economic systems of their countries). Decreasing government funding, internationalization, increasing autonomy, formation of external and internal quality assurance processes, involvement of social partners in the university management processes have caused changes in the way universities operate and partner with other higher education institutions, and have shaped and continue to shape the need for improving the management of universities (Dobrovič \& Timková, 2017). In accordance with the policy currently cultivated in Europe, the Europe 2020 strategy features plans to improve higher education graduation indicators and shorten the time required to achieve higher education, while maintaining the same academic standards. The Europe 2020 objective pertaining to $\mathrm{HE}$ is for at least $40 \%$ of people between 30 and 34 to have acquired some sort of higher education. This is a general margin for all EU member states, although individual countries retain the possibility to set a national margin, which may be either above or below $40 \%$ (European Commission, 2015).

Higher education policy is part of the wider European reform agenda. Bologna reforms were launched to create inclusive higher education where mobility of study programs, students and 
academic staff could ensure better use and practical application of knowledge (Stojanovski et al., 2018). The goal of the guidelines for Lithuanian science and innovation system is to initiate the renewal of the Lithuanian science and innovation policy and to set the general directions of this policy. The guidelines, based on which, the development of innovations and activities related to scientific progress should be implemented, includes focused coordination, implementation of strategic planning, an effective education system, faster scientific progress, creation and implementation of innovations in the public as well as business sector. In 2009, the Lithuanian study system reform began, aimed at shaping and implementing a policy oriented toward the improvement of study quality. In 2016, the Parliament of the Republic of Lithuania passed a decree which suggested that the Government or a competent institution (institutions) authorized by it should prepare proposals for optimizing the network of national universities and submit them to the Parliament. Currently, the restructuring of the Lithuanian university network is still being coordinated.

\section{RESEARCH OBJECTIVE, METHODOLOGY AND DATA}

Determining the needs and expectations of the interested parties within the education system, regular research, improvement of education quality based on the needs of all the interested parties are among the main tasks in the functioning of universities.

In Lithuania, the main (largest) universities (Mykolas Romeris University is one of them) are constantly competing to attract students. The factors behind this competition became particularly apparent after the Parliament made the decision to lower the number of universities. Mykolas Romeris University (MRU) has become the first Lithuanian University to change its status becoming a public body in 2010. After the reform, the university has formulated its strategic goals: to become established in the market of continuous training, to develop electronic studies and scientific activities. The implemented changes allowed the university to successfully operate in a competitive environment, integrating into the competitive European and global field of higher education and joining international networks. The internationality of studies remains a priority in the university new strategy, as it aims for the leading position in training top qualification professionals in the field of social sciences.

An international group of researches accomplished the research. The research goal is to determine whether or not there is a difference between the general higher education trends in Lithuania and the trends observed at MRU. The research was accomplished during March 2018 - April 2018, also statistical data of 2017-2018 years was analyzed. A study has been conducted on the trends and links between Lithuanian higher education and Mykolas Romeris University. The research analyzed problems on the state level, so the research employed an analysis of secondary data. The data concerning a number of students, lecturers, and focus about financial funds of studies in Lithuania were collected. There was the method of collection of data - analysis of documents used. Data was received from the Lithuanian Department of Statistics (Statistics Lithuania, 2019), Mykolas Romeris University Rector's Reports (Mykolo Romerio universitetas, 2019). Data of these sources are presented openly.

For the data analysis, there were applied the descriptive statistical methods (presentation of graphics). Data dynamics were evaluated by calculating the relative dynamic index and the absolute dynamic index. The Excel 2013 program was applied. Analyzing the relation of data, the indexes or speed of change are calculated (Diggle \& Chetwynd, 2013). The strength of a link 
is assessed using the Pearson correlation coefficient (Newbold et al., 2013). The calculation of correlation coefficient was accomplished by IBM SPSS 24.0 program, so the importance of the correlation coefficient is determined according to the probability value or asymptotic significance p-value.

Analysis of secondary data provides an opportunity to examine large-scale problems. The investigator himself is not able to collect such data on his own. However, it must be noted that there are certain shortcomings. For example, not all data is provided on a Lithuanian scale, MRU data is more detailed. The latest data is only from 2017. This does not allow us to assess and evaluate the current situation.

\section{RESULTS AND DISCUSSION}

Due to demographic problems and high emigration, the number of residents in Lithuania is constantly decreasing. This also affects the number of Lithuanian universities. From analyzing the information (Figure 2), it is evident that before the 2008 financial crisis, the number of students in Lithuania was increasing, peaking in 2009 , and then began to decline.

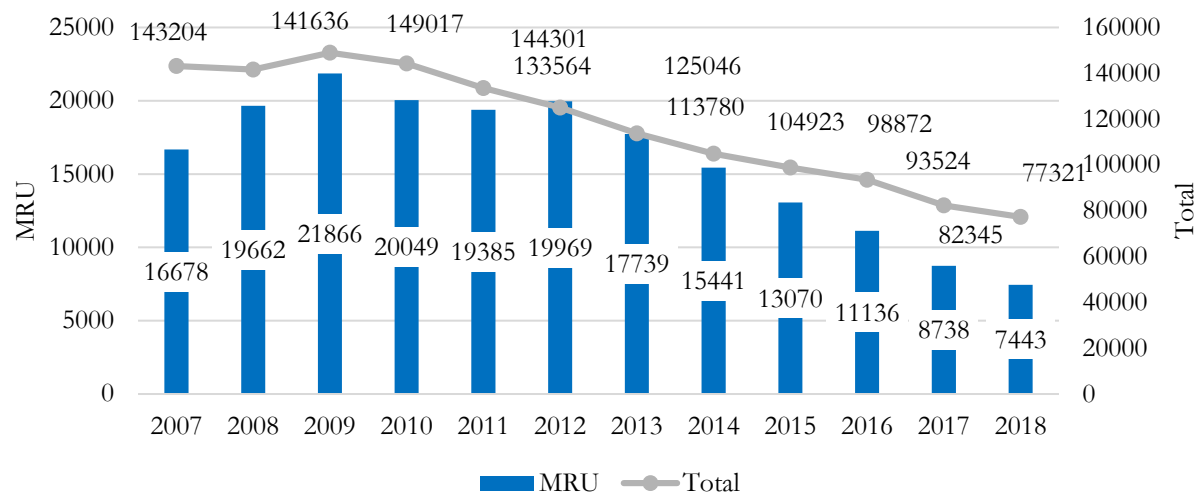

Fig. 2 - Dynamics of students' number in Lithuania. Source: Statistics Lithuania (2019); Mykolas Romeris University (2019).

The number of students in MRU followed a similar pattern but it can be observed that thanks to the university management reform that started in 2010, the decline was stopped, and in 2012, the number of students in MRU began to grow once again. This demonstrated the effectiveness of MRU management reforms. However, since 2013, a constant decrease in the number of MRU students is observed not just in Lithuania but also in MRU.

To compare the trends in students' number dynamics in Lithuania and MRU, the Pearson correlation coefficient was calculated. There are formulated the following hypotheses:

$H_{0:}$ the correlation coefficient of students' number in Lithuania and students' number in MRU is null.

$H_{1}$ : the correlation coefficient of students' number in Lithuania and students' number in MRU is not null. 
The Pearson correlation coefficient: $r=0.93, p-$ value $=0.000$. Optional materiality level $\alpha=0.05$ $>p-$ value, correlation is significant, proved the hypothesis $H_{1}$. The Pearson coefficient shows a strong link between the students' number dynamics in Lithuania and MRU, but there are some differences.

Calculating the relative index $Q_{i}=y_{i} / y_{i-1}$ and absolute index $G_{i}=y_{i} / y_{0}$ (here $y_{0}, y_{i}, y_{i-1}-$ annual students' number) of the dynamics allows assessing the process with more precision (Figure 3).
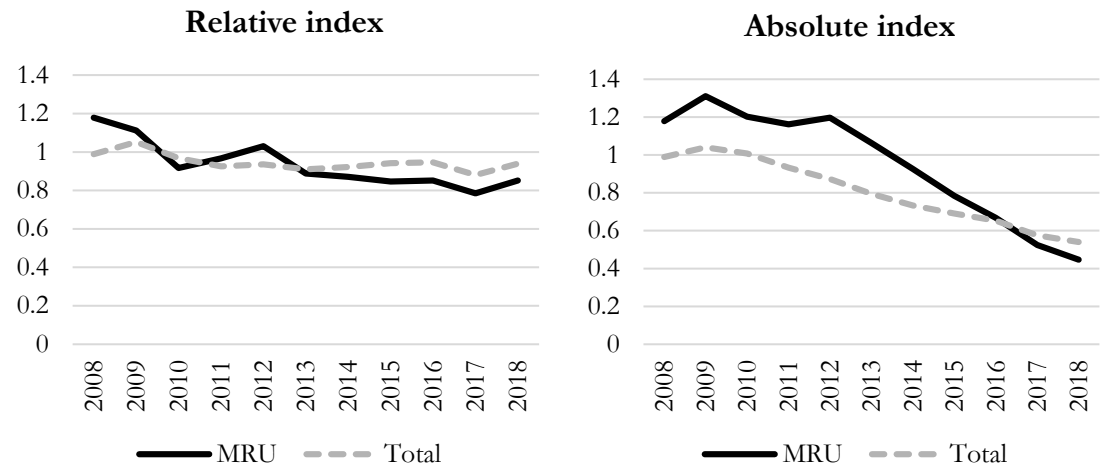

Fig. 3 - Relative and absolute indexes of students' number dynamics. Source: own research

The absolute index dynamics practically echoes the data dynamically. The absolute index of the students' number in Lithuanian and in MRU shows that the number of students was increasing up to 2009. Afterwards, the students' number dynamic in Lithuania becomes negative. The dynamic of MRU students' numbers remained negative for 2010 and 2011, in 2012, a positive dynamics is observed, and later on, from 2013 onwards - negative again. But given the very strong correlation between the number of students in Lithuania and MRU, it is natural. The relative index shows a fluctuation in students' numbers. It is particularly noticeable in terms of MRU. In 2010-2012, the MRU relative index was growing faster than that of Lithuania. This confirms the effectiveness of MRU management reforms. In 2013, indexes become equal, and from 2014 onwards, the Lithuanian relative index begins to grow, while MRU decreases. One of the reasons for this situation is a decrease in appropriations in the Lithuanian state budget for MRU stipends and studies (Figure 4). This signifies a decrease in state-funded slots. The university had to admit more Lithuanian students who have to pay for their education. However, it can be noticed that since 2016, the dynamics of the relative indexes of the number of Lithuanian and MRU students has not changed. Although the total number of students in Lithuania is starting to decline, Mykolas Romeris University remains one of the most attractive universities in the field of social sciences. With the decreasing number of students in all stages of education in Lithuania, the number of MRU students remains quite stable. 


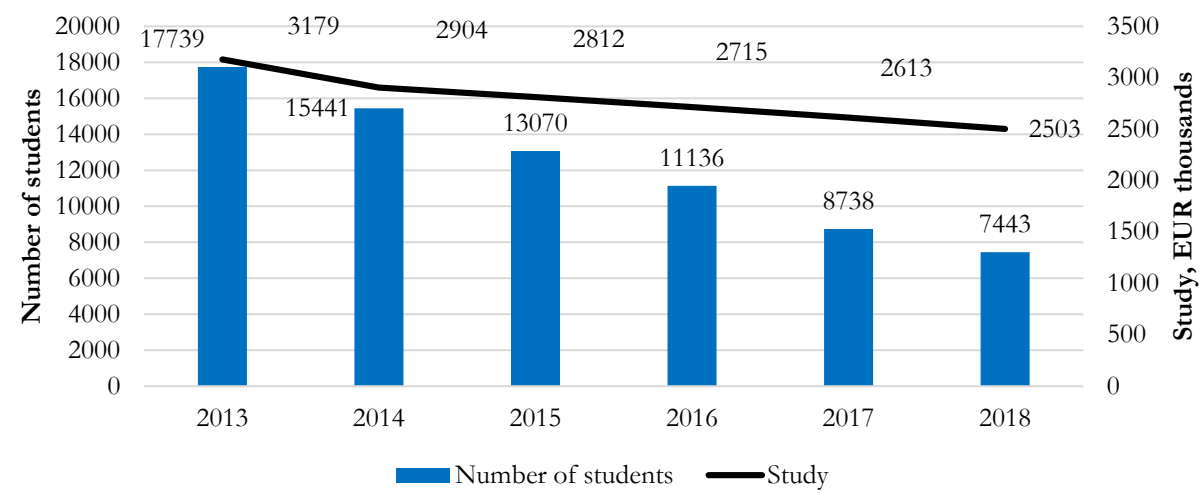

Fig. 4 - Dynamics of Lithuanian state budget appropriations for studies (MRU) and dynamics of the number of students (MRU). Source: Statistics Lithuania, 2019; Mykolas Romeris University, 2019

Particularly noticeable are the differences in the budget appropriations for stipends in other Lithuanian universities and MRU (Table 1 and Figure 5).

Tab. 1 - Lithuanian state budget appropriations in thousands of EUR. Source: Statistics Lithuania (2019); Mykolas Romeris University (2019)

\begin{tabular}{|l|c|c|c|c|c|c|}
\hline & 2013 & 2014 & 2015 & 2016 & 2017 & 2018 \\
\hline Stipend, MRU (total) & 359 & 301 & 279 & 329 & 356 & 470 \\
\hline $\begin{array}{l}\text { Stipend, Lithuania } \\
\text { (total) }\end{array}$ & 14875 & 13120 & 12580 & 14457 & 14221 & 14514 \\
\hline Study, MRU (total) & 3179 & 2904 & 2812 & 2715 & 2613 & 2503 \\
\hline $\begin{array}{l}\text { Study, Lithuania } \\
\text { (total) }\end{array}$ & 102710 & 100829 & 97832 & 96760 & 95588 & 95280 \\
\hline
\end{tabular}

This is also indicated by the Pearson correlation coefficient for Study, MRU and Study, Lithuania; for Stipend, MRU and Stipend, Lithuania.

For Study, MRU and Study, Lithuania, there are formulated the following hypotheses:

$\mathrm{H}_{0}$ : Study, MRU and Study, Lithuania, the correlation coefficient is null.

$\mathrm{H}_{1}$ : Study, MRU and Study, Lithuania, the correlation coefficient is not null.

The Pearson correlation coefficient $r=0.97, p-v a l u e=0.000$. Optional materiality level $\alpha=0.05$

$>p$-value, correlation is significant, proved the hypothesis $\mathrm{H}_{1}$. The Pearson coefficient shows a strong positive link.

For Stipend, MRU and Stipend, Lithuania, there are formulated the following hypotheses:

$\mathrm{H}_{0}$ : Stipend, MRU and Stipend, Lithuania, the correlation coefficient is null.

$\mathrm{H}_{1}$ : Stipend, MRU and Stipend, Lithuania, the correlation coefficient is not null. 
The Pearson correlation coefficient is $r=0.68, p-$ value $=0.000$. Optional materiality level $\alpha$ $=0.05>p-$ value, correlation is significant, proved the hypothesis $\mathrm{H}_{1}$. The Pearson coefficient shows an average positive link.
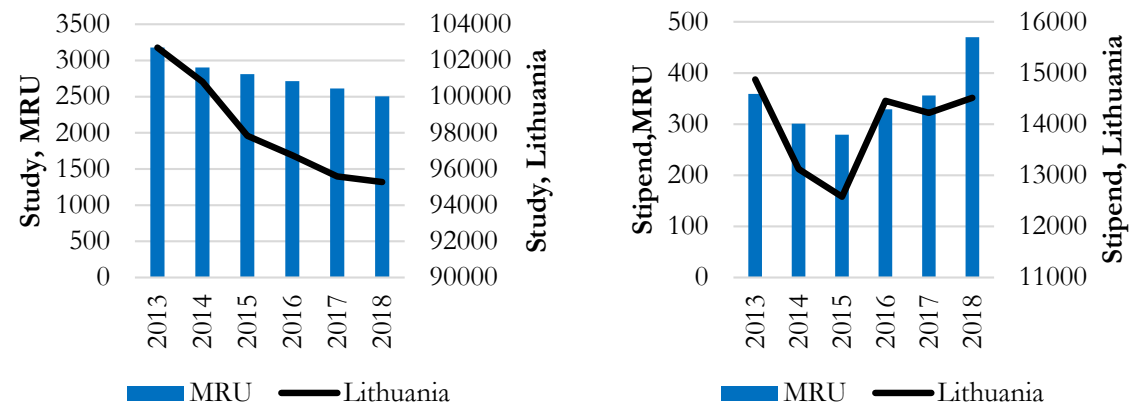

Fig. 5 - Lithuanian state budget appropriations in thousands of EUR. Source: Statistics Lithuania (2019); Mykolas Romeris University (2019)

This data show that budget appropriations for studies and stipends are diminishing not only at MRU but also throughout Lithuania. Further, budget appropriations for stipends at MRU have decreased more than the average in Lithuania.

Calculating Lithuanian state budget appropriations per individual student produces even more interesting results (Figure 6).

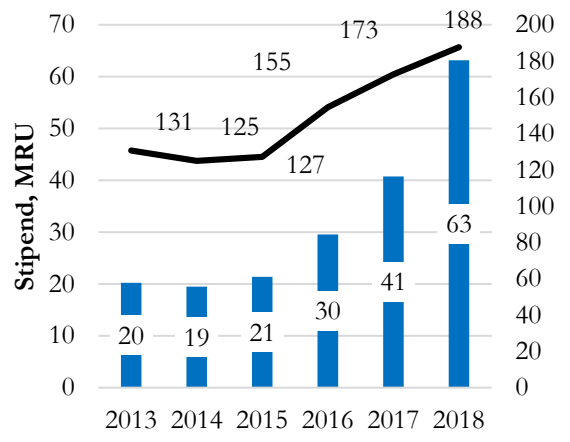

MRU Lithuania

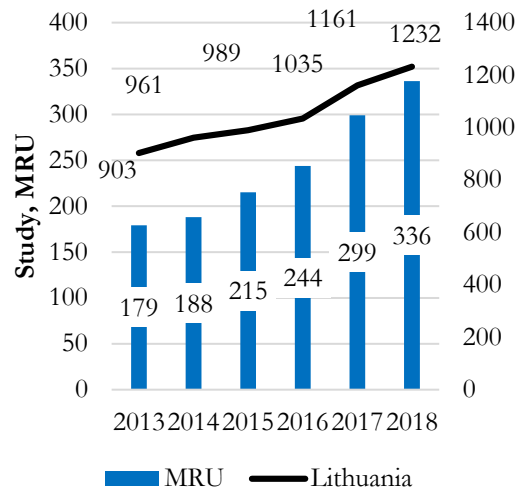

Fig. 6-Lithuanian state budget appropriations per individual student in EUR. Source: own research

The appropriation average in Lithuania is 4-6 times higher than at MRU, a result which shows a clear cut reason for ongoing decrease in the number of students admitted for study at MRU (Table 2 and Figure 7). 
Tab. 2 - Lithuanian state budget appropriations in thousands of EUR. Source: Mykolas Romeris University (2019)

\begin{tabular}{|l|l|l|l|l|l|l|l|l|l|l|l|}
\hline & 2007 & 2008 & 2009 & 2010 & 2011 & 2012 & 2013 & 2014 & 2015 & 2016 & 2017 \\
\hline MRU* & 6677 & 7021 & 6800 & 5232 & 5121 & 4449 & 4149 & 4217 & 3173 & 1919 & 1727 \\
\hline $\begin{array}{l}\text { Relative } \\
\text { index }\end{array}$ & 1.05 & 0.97 & 0.77 & 0.98 & 0.87 & 0.93 & 1.02 & 0.75 & 0.60 & 0.90 \\
\hline $\begin{array}{l}\text { Absolute } \\
\text { index }\end{array}$ & 1.05 & 1.02 & 0.78 & 0.77 & 0.67 & 0.62 & 0.63 & 0.48 & 0.29 & 0.26 \\
\hline
\end{tabular}

* Number of students admitted to study at MRU

The calculated relative index $Q_{i}=y_{i} / y_{i-1}$ and absolute index $G_{i}=y_{i} / y_{0}$ (here $y_{0}, y_{i}, y_{i-1}$ - students' number) of dynamics reveals the specificity of the process.
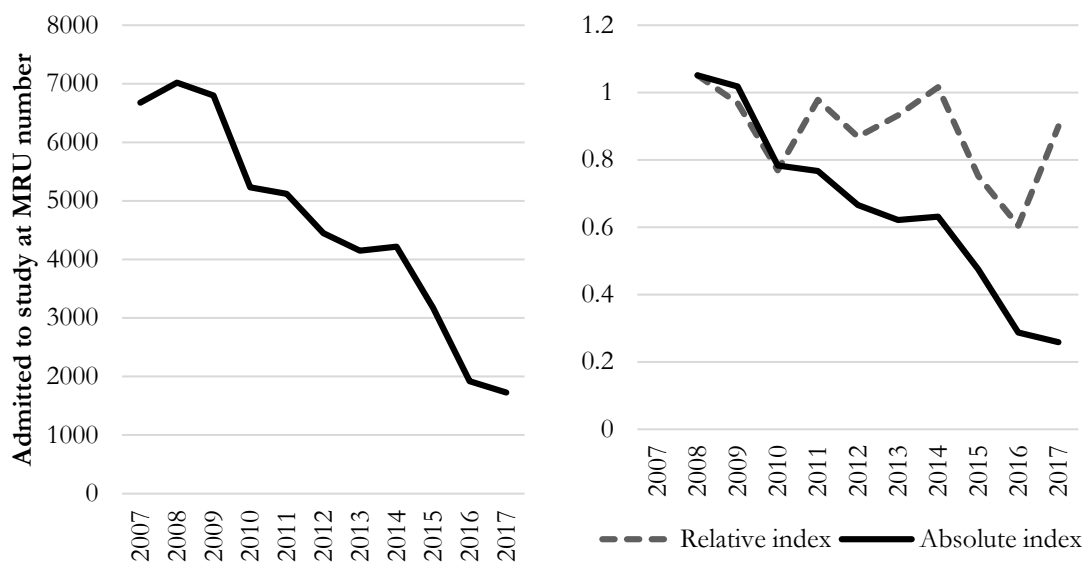

Fig. 7 - Dynamics of the number of students admitted to study at MRU. Source: Mykolas Romeris University (2019)

The absolute index shows that the number of students admitted to study at MRU did not decrease at an even rate. The decrease partially stabilized after the 2009 MRU management reform. Only after the 2013 financial decline, did negative dynamics begin to show up again. The relative index indicates an even more interesting process: between 2009 and 2014, a positive trend was nearly reached. 2015 and 2016 again show negative dynamics, with the number of students admitted to study at MRU finally showing a positive tendency in 2016.

These results could be explained through separately analyzing the number of students admitted to 1 st and 2nd cycle studies (Figure 8). Since 2016, the number of students admitted to study in the 2 nd cycle has been increasing. This shows that students from other universities choose 2 nd cycle studies at MRU.

Modernization and internationalization of the study content remained a priority in the university strategy to achieve the leading position in the field of social science education, i.e. graduating the largest number of qualified professionals. MRU focuses on internationalisation of studies. 
In 2018, twenty-two study programmes were implemented in English. Nine joint programs were implemented with universities of Finland, Austria, France, Ukraine, South Korea, Estonia and Latvia. Five validated or two degrees programs were implemented with universities of France and United Kingdom of Britain. There were cconducted eight national programs in English, there citizens from abroad and Lithuania studied. This has made MRU more attractive to prospective students.

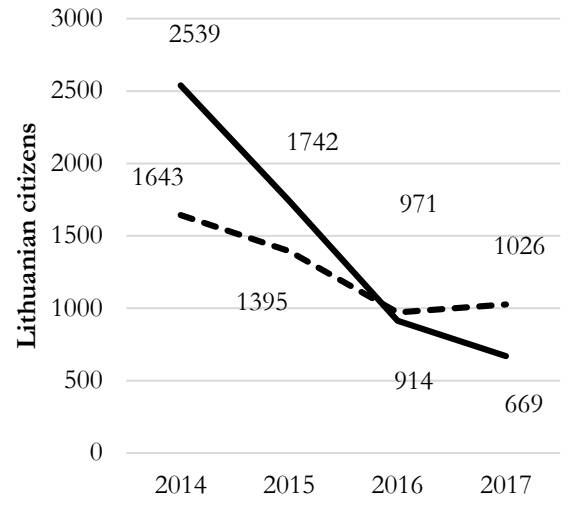

I level of studies - - II level of studies

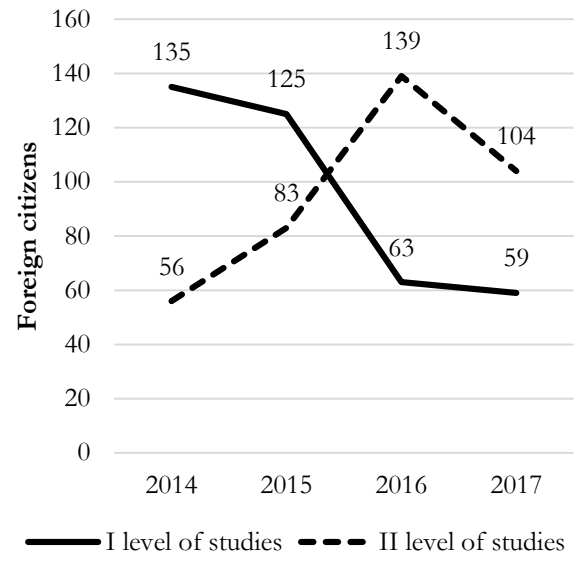

Fig. 8 - Dynamics of the number of students admitted to study at MRU (1st and 2nd cycle). Source: Mykolas Romeris University (2019)

MRU is also been made more attractive through international student exchange (Figure 9). Study content, academic exchanges, and integrated international mobility (for studies or internships) within a system of innovative study subjects have been implemented, with international study programs in cooperation with foreign partners providing students with more opportunities to acquire relevant competences and to successfully enter the national and international labor market.

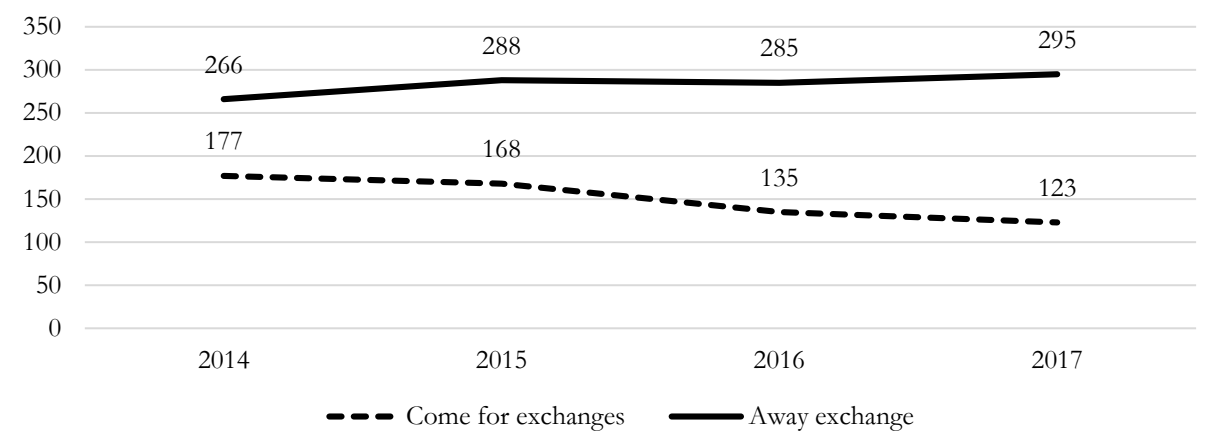

Fig. 9 - International exchange students at MRU. Source: Mykolas Romeris University (2019) 
The efficiency of the work of the lecturers at MRU has also increased. Figure 10 shows the average number of students per one lecturer at MRU and throughout Lithuania. On average, one MRU lecturer has twice as many students than elsewhere in Lithuania. This was made possible thanks to the computerization of the educational process and through distance learning methods.

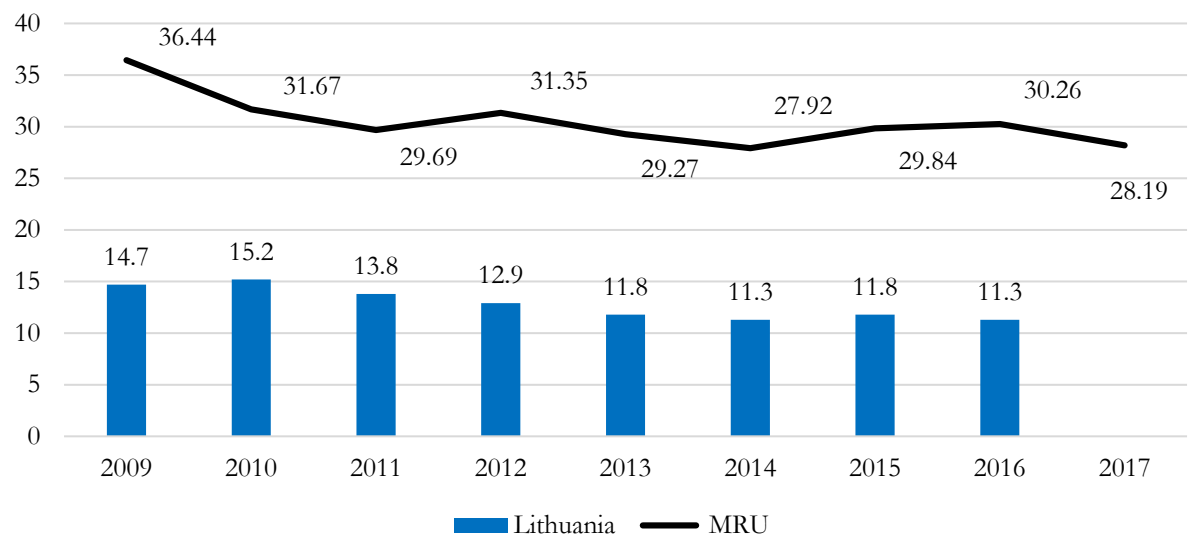

Fig. 10 - Number of students per one lecturer. Source: Statistics Lithuania (2019), Mykolas Romeris University (2019)

The university management continues to adapt to changes in the student numbers (Figure 11). As the number decreases, decreases follow in positions of lecturers as well as other staff (scientific and administrative), e.g. in one year (2016-2017), the number of lecturer jobs decreased from 368 to 310 . Due to changes in the way work activities are organized, the number of administrative jobs along with jobs held by staff also decreased from 244 to 224 in one year (Mykolo Romerio universitetas 2019).

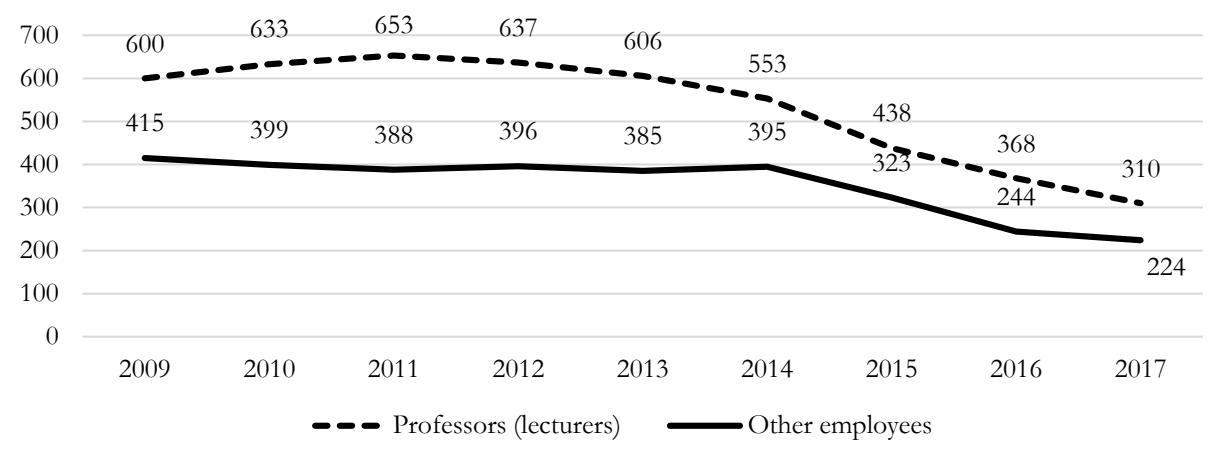

Fig. 11 - Mykolas Romeris University staff (number of employees). Source: Mykolas Romeris University (2019)

The Pearson correlation coefficient for the number of lecturers and other staff was calculated, with the following hypotheses formulated: 
$\mathrm{H}_{0}$ : the number of lecturers and another staff correlation coefficient is null.

$\mathrm{H}_{1}$ : the number of lecturers and another staff correlation coefficient is not null.

The Pearson correlation coefficient $r=0.95, p-$ value $=0.000$. Optional materiality level $\alpha=$ $0.05>p-$ value, the correlation is significant, hypothesis $\mathrm{H}_{1}$ was proven. The Pearson coefficient shows a strong positive link.

The dynamics of the funds received by the university and staff remuneration are provided in Figure 12.

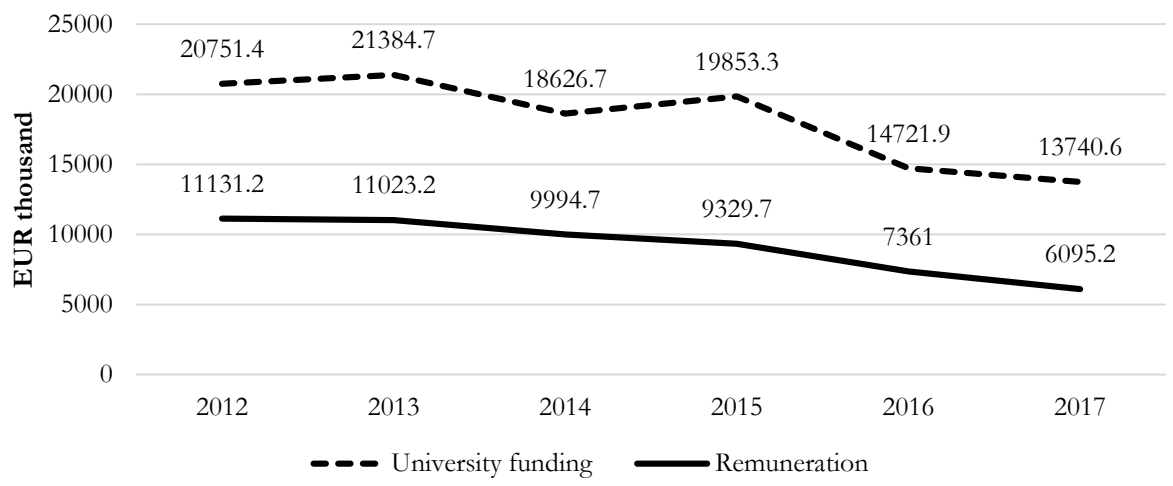

Fig. 12 - Dynamics of funds received by the university and remuneration. Source: Mylkolas Romeris University (2019)

The Pearson correlation coefficient was calculated for these sets of data, with the following hypotheses formulated:

$\mathrm{H}_{0}$ : the correlation coefficient of university and staff remuneration is null.

$\mathrm{H}_{1}$ : the correlation coefficient of university and staff remuneration is not null. The Pearson correlation coefficient $r=0.96, p-$ value $=0.000$. Optional materiality level $\alpha=0.05>p-$ value, the correlation is significant, $\mathrm{H}_{1}$ hypothesis was proved. The Pearson coefficient shows a strong positive link.

It can be argued that in spite of decreasing funding, MRU strives to maintain a level of employee redemption as well as not to lose good employees.

The study showed that the modernization of the MRU management has positively affected the MRU's position on the Lithuanian higher education market.

\section{CONCLUSION}

Significant demographic, economic and political changes demand improvements in higher education management methods in both Lithuania and the European Union. The European Union has issued numerous programmed documents regulating higher education reform over the past years. Accordingly, a higher education reform program was initiated in Lithuania in 2009, and in 
2017 it moved to a new stage. Due to high emigration and the steady ageing of the Lithuanian population, the national government has decided to decrease the number of universities.

The scientific field both globally and in Lithuania must change and accept innovations in the internal management of universities. The competition within higher education and newly arising challenges have caused universities to reorganize their management. Management methods, leadership, profitability criteria, investment, as well as marketing strategies adopted from business have become common in higher education. Now, all universities are forced to modernize their operations and implement advanced management methods in their internal management to meet the demands of globalization. However, haphazardly merging universities and making unfounded changes to a nation's university network is not acceptable.

In response to the rapid environmental change, the number of study programs has been significantly reduced, and programs that duplicate those at other universities have been dropped. The rest of the programs have been refined, focusing on areas where MRU has exclusivity as well as the highest level of expertise and scientific potential. The new MRU financial management system has helped optimize costs and balance the budget, allowing the administration to focus on key goals and to plan ahead. In the short term, MRU has also implemented a structural administrative overhaul, and the university budget has shown a positive balance.

The hypothesis that there is a strong link between the dynamics of student number in Lithuania and MRU was proved. The fact that budget appropriations for studies and scholarships are diminishing not only at MRU but also throughout Lithuania has also been demonstrated. Nevertheless, budget appropriations for stipends at MRU have decreased to more than is the average in Lithuania, with the hypothesis that their development is the same not proven. The efficiency of the work of lecturers at MRU has increased, with one MRU lecturer having on average twice as many students than elsewhere in Lithuania. Despite funding decreases, MRU strives to maintain a level of employee redemption and strives not to lose good employees.

In the context of the shrinking total number of students, a positive trend can be seen in the steady flow of incoming international study exchange students as well as in the number of students from other countries seeking a MRU degree.

The research results show that despite the Lithuanian government's policy of decreasing the funding for universities as well as decreasing the total number of universities, Mykolas Romeris University may survive under the conditions of the new higher education reform. Still, it remains important to maintain the autonomy of MRU as well as its effective educational and publication practices.

\section{References}

1. Baltaru, R. D., \& Soysal, Y. N. (2018). Administrators in higher education: organizational expansion in a transforming institution. The International Journal of Higher Education Research, 76 (2), 213-229. http://dx.doi.org/10.1007/s10734-017-0204-3

2. Becket, N., \& Brooks, M. (2008). Quality Management Practice in Higher Education What Quality Are We Actually Enhancing? Journal of Hospitality, Leisure, Sport and Tourism Education, 7 (1), 40-54. http://dx.doi.org/10.3794/johlste.71.174 
3. Bilevičiūtè, E., Bilevičienè, T., \& Raišienè, A. G. (2012). Social innovations in the management of higher education: the case of Mykolas Romeris University. Public administration and regional development, 8(2), 75-88.

4. Blagojevic Popovic, O., Nikic, V., Bulatovic, I., \& Delibasic, M. (2018). Modeling Perceived Quality, Customer Satisfaction and Probability of Guest Returning to the Destination. Montenegrin Journal of Economics, 14 (1), 69-78. https://doi.org/10.14254/1800-5845/2018.141.5

5. Buřita, L., Hrušecká, D., Pivnička, M., \& Rosman P. (2018). The Use of Knowledge Management Systems and Event-B Modelling in a Lean Enterprise. Journal of Competitiveness, 10 (1), 40-53. http://dx.doi.org/10.7441/joc.2018.01.03

6. Craig, R. (2017). The Top 10 Higher Education Issues We All Agree On. Retrieved December 10, 2018, from https://www.forbes.com/sites/ryancraig/2017/01/20/the-top-10higher-education-issues-we-all-agree-on/\#7dae9db6fa87

7. Diggle, P. J., \& Chetwynd, A. G. (2013). Statistics and scientific method: an introduction for students and researchers. London: Oxford University Press. http://dx.doi.org/10.1093/acprof:o so/9780199543182.001.0001

8. Dobrovič, J., \& Timková, V. (2017). Examination of Factors Affecting the Implementation of Organizational Changes. Journal of Competitiveness, 9 (4), 5-17. http://dx.doi.org/10.7441/ joc.2017.04.01

9. European Commission. (2015). Strategic framework - Education and Training 2020. Retrieved December 10, 2018, from http://ec.europa.eu/education/policy/strategicframework/index_en.htm

10. European Commission. (2017). Communication from the Commission to the European Parliament, the Council, the European Economic and Social Committee and the Committee of the Regions on a renewed EU agenda for higher education. COM (2017) 247 final. Retrieved December 10, 2018, from https://eur-lex.europa.eu/legal-content/EN/ TXT/PDF/?uri=CELEX:52017DC0247\&from=DA

11. Eurostat. (2019). Retrieved December 10, 2019, from https://ec.europa.eu/eurostat

12. Integrating academic recognition and quality assurance: practical recommendations. (2019). SKVC. Vilnius, Lithuania. Retrieved September 10, 2019, from https://eua.eu/downloads/ content/lireqa_recommendations_final_version_web.pdf

13. Ginevicius, R., Gedvilaite, D., Stasiukynas, A., \& Sliogeriene, J. (2018). Quantitative Assessment of the Dynamics of the Economic Development of Socioeconomic Systems Based on the MDD Method. Inzinerine Ekonomika-Engineering Economics, 29 (3), 264-271. https://doi.org/10.5755/j01.ee.29.3.20444

14. Gižienè, V., Simonavičienè, Ž., \& Jankauskaitė, J. (2008). Aukštojo mokslo finansavimo itaka lietuvos darbo rinkai. Economics and Management, 13 (1), 505-510.

15. Grizane, T., Sannikova, A., \& Jasaitis, J. (2017). Impact of regional higher education institutions on the convergence of regions. Economic Science for Rural Development Conference Proceedings, 44 (1), 44-51. 
16. Koisova, E., Masarova, J., \& Habanik, J. (2018). Regional Differences in the Labour Market in Slovakia and the Czech Republic. Journal of Competitiveness, 10 (2), 104-117. http://dx.doi. org/10.7441/joc.2018.02.07

17. Liu, J. (2018). A Comparative Study of the Effect of Bologna Process on the Italian Higher Education and Czech Higher Education. Education Reform Journal, 3 (1), 24-31. http://dx.doi. org/10.22596/erj2018.0301.24.31

18. Mykolas Romeris University. 2019. Vilnius. Retrieved December 10, 2019, from https:// www.mruni.eu/lt/universitetas/apie_mru/dokumentai/rektoriaus_ataskaitos/.

19. Newbold, P., Carlson, W. L., \& Thorne, B. M. (2013). Statistics for business and economics. Harlow: Pearson Education.

20. Noaman, A. Y., Ragab, A. H. M., Madbouly, A. J., Khedra, A. M., \& Fayoumi, A. G. (2017). Higher education quality assessment model: towards achieving educational quality standard. Studies in Higher Education, 42 (1), 23-46. https://doi.org/10.1080/03075079.2015.1 034262

21. Pârvu, I., \& Sandu, C. (2019). Perspectives on measuring the quality of higher education services. Journal of Academic Research in Economics, 11 (2), 389-398.

22. Prisăcariu, A. D. (2015). Authority and Power Allocation in the Quality Assurance of Higher Education - A Systemic Approach. Contemporary Research on Organization Management and Administration, 3 (1), 50-61.

23. Pruskus, V., Palevičiūtè, O., \& Kocai, E. (2015). Studentų studijų kokybès vertinimas ir jų lūkesčiai (LEU atvejis). Coactivity: Pbilology, Educology, 23 (1), 14-25.

24. Rogers, N. M. (2019). Why change? A practitioner's perspective on why and how universities tackle organisational change (or don't). Perspectives: Policy and Practice in Higher Education, 23 (4), 152-157. https://doi.org/10.1080/13603108.2019.1581850

25. Rudzevičius, J. (2007). Studijų kokybès vadybos sistemų tyrimas. Ekonomika, 80 (1), 51-69.

26. Serafinas, D., \& Ruzevičius, J. (2009). Aukštujų mokyklų veiklos tobulinimo pokyčiu kontekste iž̌valgos. Economics \& Management, 14 (1), 1084-1090.

27. Skrbinjek, V., \& Lesjak, D. (2018). Impact of the recent economic crisis on tertiary education funding - a comparative study. Int. J. Innovation and Learning, 23 (2), 123-144. http://dx.doi.org/10.1504/IJIL.2018.089619

28. Statistics Lithuania. (2019). Retrieved September 10, 2019, from https://www.stat.gov.lt/en.

29. Stojanovski, S., Denkova, J., \& Marolov, D. (2018). Higher education in the Republic of Macedonia: challenges and perspectives. Balkan Social Science Review, 11 (11), 95-113.

30. Sugruea, C., \& Solbrekkeb, T. D. (2017). Policy rhetorics and resource neutral reforms in higher education: their impact and implications. Studies in Higher Education, 42 (1), 130-148. http://dx.doi.org/10.1080/03075079.2015.1036848

31. Ungerman, O., Dedkova, J., \& Gurinova, K. (2018). The Impact of Marketing Innovation on the Competitiveness of Enterprises in the Context of Industry 4.0. Journal of Competitiveness, 10 (2), 132-148. http://dx.doi.org/10.7441/joc.2018.02.09 
32. Valioniene, E. (2016). Social transformations impact on transfer of knowhow between lecturers and students: causes and possibilities. Contemporary Research on Organization Management and Administration, 4 (1), 67-77.

33. Vázquez-Burgete, J.L., Lanero, A., Raisiene, A.G., \& Purificación García, M. (2012) Entrepreneurship education in humanities and social sciences: are students qualified to start a business? Business: Theory and Practice, 13 (1), 27-35.

\section{Contact information}

Prof. dr. Egle Bileviciute

Mykolas Romeris University

Mykolas Romeris Law School

Ateities 20, LT-08303, Vilnius

Lithuania

E-mail:eglek@mruni.eu

ORCID: 0000-0003-4142-3774

Prof. dr. Romualdas Draksas

Mykolas Romeris University

Mykolas Romeris Law School

Ateities 20, LT-08303, Vilnius

Lithuania

E-mail:romualdas.draksas@dmsp.lt

Assoc. prof. dr. Andrius Nevera

Mykolas Romeris University

Mykolas Romeris Law School

Ateities 20, LT-08303, Vilnius

Lithuania

E-mail: andrius.nevera@gmail.com

Prof. dr. Milda Vainiūte,

Mykolas Romeris University

Mykolas Romeris Law School

Ateities 20, LT-08303, Vilnius

Lithuania

Email:milda.v@mruni.eu 